\title{
Effect of sowing date and seed rate on crop development and grain production of winter wheat
}

\author{
A. Darwinkel, B. A. ten Hag and J. Kuizenga \\ Research Station for Arable Farming and Field Production of Vegetables, Edelhert- \\ weg 1 , Lelystad, the Netherlands
}

Accepted: 18 February 1977

Key words: winter wheat, grain yield, sowing date, seed rate, disease control, yield components, tiller age

\section{Summary}

In 1974, 1975 and 1976 the influence of sowing date and seed rate on grain yield was studied with winter wheat in field experiments. In the 1975 experiment a detailed study was carried out into the pattern of grain production.

Delaying the sowing date decreased grain yield. This decrease was caused by a smaller number of grains per ear and a lower grain weight. Seed rate had a positive influence on the number of ears, but a negative effect on the number of grains per ear and the grain weight. With early sowing, seed rate was found to have no effect on grain yield, due to mutual compensation of changes in yield components. With late sowing, a higher seed rate increased the number of ears so much that a higher grain yield was achieved.

The grain yield per ear depended on the age of the tiller. Tillers that emerged earlier produced more and heavier ears. The number of grains per ear and the grain weight could be related to the rate of development of the ear-bearing shoot.

The pattern of tillering was affected by the time of sowing. With early sowing, most tillers emerged in autumn and winter, whereas the late-sown wheat tillered in spring. Also, the early-sown wheat crop consisted largely of ears from early tillers, whereas the late-sown wheat had many ears from late-formed tillers.

\section{Introduction}

During the growth and development of a cereal crop, several growth stages are distinguishable in which important physiological processes occur. So, during the stages of seedling growth, tillering and stem elongation, in which initiation and differentiation of the ear take place, the number of spikelets per ear and the number of grains per spikelet are defined. The final grain yield is ascertained after anthesis by the extent of filling in the grains produced. High yields can only be obtained if sufficient green leaves and ears are available. 
The development of the crop can be influenced by cultivation measures. Besides directly influencing the development of the individual plant, cultivation measures indirectly affect the occurrence of lodging and diseases in cereal crops. A proper choice of cultivation measures also contributes to high and reliable yields. One of these measures is the choice of the date of sowing.

The influence of sowing date on grain yield has been studied in detail by Feekes (1941). His experiments showed that later sowing decreased the yield of winter wheat, especially at late sowing dates, due to lower grain weights. Unfortunately, in these experiments the first sowing date was in the second half of October. Lower grain yields caused by delaying sowing were also found by Beech \& Norman (1966), Henriksen (1961), Jonker (1964), Mundy \& McClean (1965) and Vez (1971).

Seed rate influences the number of ears produced. The relation between seed rate and grain yield can be graphed as a curve with a wide optimum range (Ridder, 1976). Usually the occurrence of lodging and diseases increases at higher crop densities and leads to yield reduction. To restrict lodging and diseases, much attention is paid to nitrogen fertilization (Laloux et al., 1975) and to application of fungicides (Dilz \& Schepers, 1972; Spiertz, 1973).

Sowing winter wheat very early has not received much attention, probably because of the risk of a higher incidence of diseases. To obtain more information on how sowing date, combined with seed rate and disease control, influences grain yield, a research programme was set up in 1974, 1975 and 1976. In the 1975 experiment a detailed study of crop development and resulting grain production was carried out on a small scale. The growth of the individual tillers was carefully followed and the contribution of these tillers to the grain yield was ascertained.

\section{Materials and methods}

In 1974, 1975 and 1976 field experiments were carried out with winter wheat (c.v. Lely) on a fertile, clayey soil $(\mathrm{pH}=7.4)$ in the Flevopolder. Some data of the treatments are given below:

\begin{tabular}{|c|c|c|c|}
\hline & $1973 / 74$ & $1974 / 75$ & $1975 / 76$ \\
\hline Sowing dates $\mathrm{t} 1$ & $3 / 10$ & $3 / 10$ & $26 / 9$ \\
\hline $\mathrm{t} 2$ & $25 / 10$ & $6 / 11$ & $3 / 11$ \\
\hline $\mathrm{t} 3$ & $19 / 11$ & $3 / 12$ & $11 / 12$ \\
\hline Seed rate $(\mathrm{kg} / \mathrm{ha}) \mathrm{s} 1$ & 90 & 80 & 80 \\
\hline s2 & 180 & 160 & 160 \\
\hline N-dressing (kg/ha) & $35+35$ & $65+65$ & $80+50$ \\
\hline Fungicide & $14 / 6$ & $19 / 6$ & $15 / 6$ \\
\hline
\end{tabular}

Sowing at a row width of $25 \mathrm{~cm}$ always took place shortly after tillage with a spading-machine. The nitrogen fertilization was based on the amount of mineral-N in the soil in mid-February and was applied as a split dressing. Control of leaf and ear diseases was carried out during anthesis with Carbendazim-Maneb (Bavistin M, $4 \mathrm{~kg} / \mathrm{ha}$ ).

The scheme was a split plot design with disease control as sub-plot in 3 replicates. 
Table 1. Number of plants and ears, grain yield and grain weight. Average of sowing dates, seed rates and fungicide treatments.

\begin{tabular}{lllll}
\hline Year & $\begin{array}{l}\text { Number of } \\
\text { plants } / \mathrm{m}^{2}\end{array}$ & $\begin{array}{l}\text { Number of } \\
\text { ears } / \mathrm{m}^{2}\end{array}$ & $\begin{array}{l}\text { Grain yield } \\
\left(\mathrm{g} / \mathrm{m}^{2}\right)\end{array}$ & $\begin{array}{l}\text { Grain weight } \\
\text { (mg/grain) }\end{array}$ \\
1974 & 234 & 411 & 726 & 44.0 \\
1975 & 166 & 340 & 792 & 48.3 \\
1976 & 217 & 431 & 696 & 38.8 \\
\hline
\end{tabular}

The plot size was $60 \mathrm{~m}^{2}$, of which $36 \mathrm{~m}^{2}$ was harvested by a combine.

In the 1975 experiment a detailed study was carried out to analyse the pattern of grain production of the crop. In each plot, a one-metre-long row $\left(=1 / 4 \mathrm{~m}^{2}\right)$ was selected, with 32 and 64 plants respectively. On 8 January, 27 February and 24 March the tillers that were present were marked with coloured, plastic rings, so that they could be subdivided according to age into main shoots and early, medium and late tillers. At harvest the number of ears, the number of grains per ear, and the grain weight of these tillers were determined.

\section{Results}

\section{Field experiments}

The growing conditions in 1974, 1975 and 1976 were rather favourable for grain production. Lodging did not occur, whereas diseases appeared only in 1974 and 1975 to a small extent. Variations in crop growth and yield between the years are shown in Table 1. Conditions in 1975 were rather different: because of the very wet autumn of 1974 the seeds emerged poorly, resulting in low plant densities. Moreover, tillering was not favourable and consequently rather low crop densities occurred. Growth conditions during the period of grain-filling in 1975 were very favourable and the grain yield was very high. In contrast, in 1976 maturation was accelerated by hot and dry weather and the grain yield was limited due to a low grain weight.

Crop density. Although the average number of plants was practically equal for all sowing dates, clear differences in number of plants existed in 1974 and 1975, caused by differences in emergence (Table 2). The emergence depended on the soil conditions at sowing. In autumn 1973 the conditions at the later sowing dates were better, but in the autumn of 1974 they were worse than at early sowing. Sowing at different sowing dates under similar conditions, as occurred in the autumn of 1975 , resulted in an equal number of plants.

Plant density was clearly influenced by the seed rate. Doubling the seed rate resulted in a corresponding increase in the number of plants.

In general, relatively few ears were formed in all experiments, including at the high seed rate. The effects of sowing date were rather small (Table 2). The first two sowing dates resulted in equal numbers of ears. At the late sowing date there were 
Table 2. Number of plants per $m^{2}$ (a) and number of ears per $m^{2}(b)$ at different sowing dates $(\mathrm{t} 1, \mathrm{t} 2$ and $\mathrm{t} 3)$ and seed rates (s1 and $\mathrm{s} 2$ ).

\begin{tabular}{|c|c|c|c|c|c|c|}
\hline \multirow[t]{2}{*}{ Year } & \multicolumn{3}{|c|}{ Low seed rate (s1) } & \multicolumn{3}{|c|}{ High seed rate (s2) } \\
\hline & $\mathrm{t} 1$ & $\mathrm{t} 2$ & $\mathrm{t} 3$ & $\mathrm{t} 1$ & $\mathrm{t} 2$ & t3 \\
\hline \multicolumn{7}{|c|}{ a) plants per $m^{2}$} \\
\hline 1974 & 134 & 161 & 166 & 252 & 327 & 364 \\
\hline 1975 & 132 & 110 & 84 & 276 & 224 & 168 \\
\hline 1976 & 146 & 146 & 152 & 300 & 272 & 286 \\
\hline Mean & 137 & 139 & 134 & 276 & 274 & 273 \\
\hline \multicolumn{7}{|c|}{ b) ears per $m^{2}$} \\
\hline 1974 & 392 & 405 & 336 & 418 & 436 & 476 \\
\hline 1975 & 308 & 340 & 303 & 352 & 364 & 374 \\
\hline 1976 & 432 & 391 & 409 & 479 & 419 & 459 \\
\hline Mean & 377 & 379 & 349 & 416 & 406 & 436 \\
\hline
\end{tabular}

fewer ears per $\mathrm{m}^{2}$ at the low seed rate, but more at the high seed rate. The number of ears was clearly influenced by the seed rate. This effect was greatest at the late sowing date. At the first two sowing dates the plants at low densities developed vigorously with many fertile tillers, so this equalized the number of ears produced at the high seed rate to some extent. At the late sowing date, this compensation was considerably less, resulting in a great difference in numbers of ears.

Grain yield. The effect of sowing date on grain yield fluctuated yearly (Table 3). The grain yields of the first and second sowing dates were erratic. The grain yield of the late sowing date clearly lagged behind. The mean yield reduction, due to the late sowing, ranged from 25 (in 1974) to $94 \mathrm{~g} / \mathrm{m}^{2}$ (in 1975).

The effect of seed rate on grain yield depended on the sowing date. No effect was found at the first and second sowing dates, but at the late sowing date the grain yield was clearly higher at the high seed rate.

Table 3. Grain yields $\left(\mathrm{g} / \mathrm{m}^{2}, 15 \%\right.$ moisture $)$ at different sowing dates, seed rates and fungicide treatments.

\begin{tabular}{|c|c|c|c|c|c|c|c|}
\hline \multirow[t]{2}{*}{ Year } & \multirow[t]{2}{*}{ Fungicide } & \multicolumn{3}{|c|}{ Low seed rate (s1) } & \multicolumn{3}{|c|}{ High seed rate (s2) } \\
\hline & & $\mathrm{t} 1$ & $\mathrm{t} 2$ & $\mathrm{t} 3$ & t1 & t2 & $\mathrm{t} 3$ \\
\hline \multirow[t]{2}{*}{1974} & - & 732 & 743 & 654 & 684 & 671 & 683 \\
\hline & + & 760 & 795 & 730 & 729 & 757 & 768 \\
\hline \multirow[t]{2}{*}{1975} & - & 768 & 784 & 648 & 823 & 787 & 723 \\
\hline & + & 825 & 841 & 741 & 883 & 872 & 803 \\
\hline \multirow[t]{2}{*}{1976} & - & 708 & 674 & 645 & 748 & 683 & 674 \\
\hline & + & 735 & 667 & 643 & 753 & 710 & 704 \\
\hline
\end{tabular}


Table 4. Grain weights (mg, $15 \%$ moisture) at different sowing dates, seed rates and fungicide treatments.

\begin{tabular}{|c|c|c|c|c|c|c|c|}
\hline \multirow[t]{2}{*}{ Year } & \multirow[t]{2}{*}{ Fungicide } & \multicolumn{3}{|c|}{ Low seed rate (s1) } & \multicolumn{3}{|c|}{ High seed rate (s2) } \\
\hline & & $\mathrm{t} 1$ & $\mathrm{t} 2$ & t3 & $\mathrm{t} 1$ & $\mathrm{t} 2$ & t3 \\
\hline \multirow{2}{*}{1974} & - & 46.7 & 43.2 & 39.4 & 46.3 & 42.5 & 39.2 \\
\hline & + & 46.3 & 46.1 & 43.7 & 45.5 & 45.4 & 43.5 \\
\hline \multirow[t]{2}{*}{1975} & - & 49.4 & 48.4 & 47.8 & 47.7 & 47.3 & 46.5 \\
\hline & + & 50.2 & 49.7 & 48.1 & 48.6 & 48.2 & 47.6 \\
\hline \multirow[t]{2}{*}{1976} & - & 40.5 & 38.1 & 36.9 & 41.0 & 38.2 & 37.0 \\
\hline & + & 41.1 & 38.3 & 37.2 & 41.5 & 38.6 & 37.5 \\
\hline
\end{tabular}

The effect of fungicide application fluctuated, depending upon the disease attack, from 13 (in 1976) to $72 \mathrm{~g} / \mathrm{m}^{2}$ (in 1975). More effective fungicide treatment occurred with later sowing and a high seed rate (Table 3 ).

Grain weights. Grain weight is largely established by growing conditions after anthesis. Thus, big differences can occur yearly (Table 1). In all trials a lower grain weight was found with later sowing (Table 4). The effect of seed rate on grain weight was small; this is undoubtedly linked with the rather low ear densities in all treatments. Application of fungicide enhanced the grain weight. In 1974 this effect was greater with later sowing.

\section{Crop analysis}

The results concerning the grain yield per ear, the number of grains per ear and the grain weight are given in Table 5. The tillers were classified according to when they appeared. The early-sown winter wheat started to tiller in late autumn and continued during winter, and many tillers could be classified as early tillers. In contrast, the late-sown wheat had no tillers on 27 February and therefore no early tillers were classified.

Tillering in spring was increased by later sowing. The early-sown wheat in particular tillered rather poorly, and had fewer tillers than the late-sown wheat at the end of April.

In early-sown wheat, the main shoots and the greater part of early tillers produced ears; the ear formation of tillers that emerged in spring was limited, especially at the high seed rate. In contrast, the late-sown wheat developed many fertile medium and late tillers and so most of the final number of ears originated from these tillers.

The number of fertile tillers depended upon the seed rate. At the high seed rate 240 main shoots were present per $\mathrm{m}^{2}$ and these shoots produced the greater part of all ears. At the low seed rate, with 120 main shoots per $\mathrm{m}^{2}$, most of the ears derived from tillers.

Because of the favourable growth conditions in 1975 from anthesis to ripeness,

Neth. J. agric. Sci. 25 (1977) 
Table 5. Grain yield per ear ( $g, 15 \%$ moisture), number of grains per ear and grain weights (mg, $15 \%$ moisture) of tillers of different age. ${ }^{1}$

\begin{tabular}{|c|c|c|c|c|c|c|}
\hline & \multicolumn{3}{|c|}{ Low seed rate $\left(120 \mathrm{pl} / \mathrm{m}^{2}\right)$} & \multicolumn{3}{|c|}{ High seed rate $\left(240 \mathrm{pl} / \mathrm{m}^{2}\right)$} \\
\hline & $\begin{array}{l}\text { yield } \\
\text { per ear }\end{array}$ & $\begin{array}{l}\text { grains } \\
\text { per ear }\end{array}$ & $\begin{array}{l}\text { grain } \\
\text { weight }\end{array}$ & $\begin{array}{l}\text { yield } \\
\text { per ear }\end{array}$ & $\begin{array}{l}\text { grains } \\
\text { per ear }\end{array}$ & $\begin{array}{l}\text { grain } \\
\text { weight }\end{array}$ \\
\hline \multicolumn{7}{|l|}{$t 1=3$ October } \\
\hline Main shoot & 3.23 & 63.0 & 51.3 & 2.64 & 53.8 & 49.1 \\
\hline Early tiller & 2.87 & 57.2 & 50.3 & 2.39 & 49.5 & 48.3 \\
\hline Medium tiller & 2.26 & 50.1 & 44.9 & 2.34 & 49.4 & 47.3 \\
\hline Late tiller & 2.20 & 49.4 & 44.6 & 1.62 & 37.6 & 43.3 \\
\hline \multicolumn{7}{|c|}{$t 2=6$ November } \\
\hline Main shoot & 3.09 & 61.4 & 50.3 & 2.56 & 51.8 & 49.5 \\
\hline Early tiller & 2.55 & 53.3 & 47.7 & 1.93 & 42.0 & 46.0 \\
\hline Medium tiller & 2.28 & 48.5 & 47.1 & 1.78 & 38.1 & 46.7 \\
\hline Late tiller & 2.22 & 47.5 & 46.7 & 1.74 & 37.5 & 46.6 \\
\hline \multicolumn{7}{|c|}{$t 3=3$ December } \\
\hline Main shoot & 2.72 & 56.7 & 48.2 & 2.36 & 49.0 & 48.2 \\
\hline Early tiller & - & - & - & - & - & 一 \\
\hline Medium tiller & 2.16 & 46.6 & 46.3 & 1.89 & 40.6 & 46.6 \\
\hline Late tiller & 2.03 & 43.4 & 46.9 & 1.72 & 37.5 & 46.0 \\
\hline
\end{tabular}

1 Early tiller: emerged before 27 february;

medium tiller: emerged between 27 february and 24 March;

late tiller: emerged after 24 March.

the grain yields per ear were high. In this experiment a very high number of grains per ear and high grain weights were measured. Later sowing resulted in a decreased grain yield per ear because the number of grains per ear decreased, as did the grain weight. Increased seed rate had a similar effect.

The yield of a cereal crop is the total yield of all ears. Table 5 shows that the grain yield per ear differed widely. The later the ear-bearing tiller was formed, the lower the yield. Main shoots had a considerably higher grain yield than tillers, especially at the high seed rate. With early sowing and at a low seed rate, early tillers also had high yields per ear. These tillers were initiated before and during winter and were able to develop favourably in the rather low-density crop. The yields of the medium and late tillers were considerably less.

The number of grains per ear depended largely upon the tiller age. The later the tiller was initiated, the lower was the number of grains. Also, late sowing and a high seed rate markedly decreased this number of grains per ear. The grain weight was similarly, but to a lesser extent, influenced by tiller age, sowing date and seed rate.

\section{Discussion}

In cereals, the important yield-determining processes are the initiation and differentiation of the ear in the pre-anthesis phase and the filling of the produced 
grains in the post-anthesis phase. It is then that the three yield components, i.e. number of ears, number of grains per ear, and grain weight, are determined.

The influence of sowing date and seed rate upon the grain yield was examined during three years. The manner in which these factors act upon the pattern of grain production, was studied by analysing the crop development.

Usually, early-sown winter wheat develops first. Tillering starts earlier, and so do the successive growth stages. Also, harvesting is earlier, though late-sown wheat reaches this stage only a few days later.

\section{Grain yield}

Sowing on the late date caused a decrease in grain yield (Table 3). Sowing earlier than the usual sowing time (which is sowing date $\mathrm{t} 2$ ) increased grain yield only slightly, but delaying the sowing time caused a distinct yield reduction, as was also found by Henriksen (1961), Jonker (1964) and Vez (1971). This decrease in grain yield was closely connected with fewer grains per ear and a lower grain weight (Table 5).

The effect of seed rate was insignificant in the first two sowing dates $\left(8 \mathrm{~g} / \mathrm{m}^{2}\right)$, but amounted to about $60 \mathrm{~g} / \mathrm{m}^{2}$ at the late sowing date. A similar interaction between sowing date and seed rate was also mentioned by Vez (1971). In our experiments the number of ears played an important role in this phenomenon (Table $2 b$ ).

Disease attack was rather small and so the effect of fungicides, sprayed shortly before anthesis, was limited. The resulting increase in grain yield could be attributed largely, but not wholly, to a higher grain weight (Tables 3 and 4). Similar data can be inferred from the results of Dilz \& Schepers (1972) and Spiertz (1973). From these results it can be deduced that not only the grain weight but also the number of grains may be increased by fungicide treatment. The higher grain weight indicates that the photosynthetic activity of leaves and ears continued for a longer time, as was also ascertained by Spiertz (1973). In our experiments the effect of fungicide treatment increased with later sowing, but was not influenced by seed rate.

\section{Tiller development}

The early-sown wheat started to tiller in autumn, so that a considerable number of tillers was already present at the end of the winter. This can be deduced from the distribution of the tillers according to age (Fig. 1). In the late-sown wheat, no tillers appeared before 27 February (Table 5). Tillering of the late-sown wheat began in the spring, continued for a longer period and achieved a higher number of tillers than the early-sown wheat. In Figure 1 this is shown by an increase of medium + late tillers with later sowing and a corresponding decrease of main shoots + early tillers.

The low rate of tillering of the early-sown wheat in spring could have resulted from strong inter-plant competition. At the end of the winter, this wheat crop consisted of many vigorous main shoots and early tillers, strongly competing for light and minerals. This competition would have been even more pronounced in treatments with a high seed rate. The results of Krishnamurthy (1963) and Willey \& Holliday (1971) showed that shading discouraged the formation of tillers and ears. 

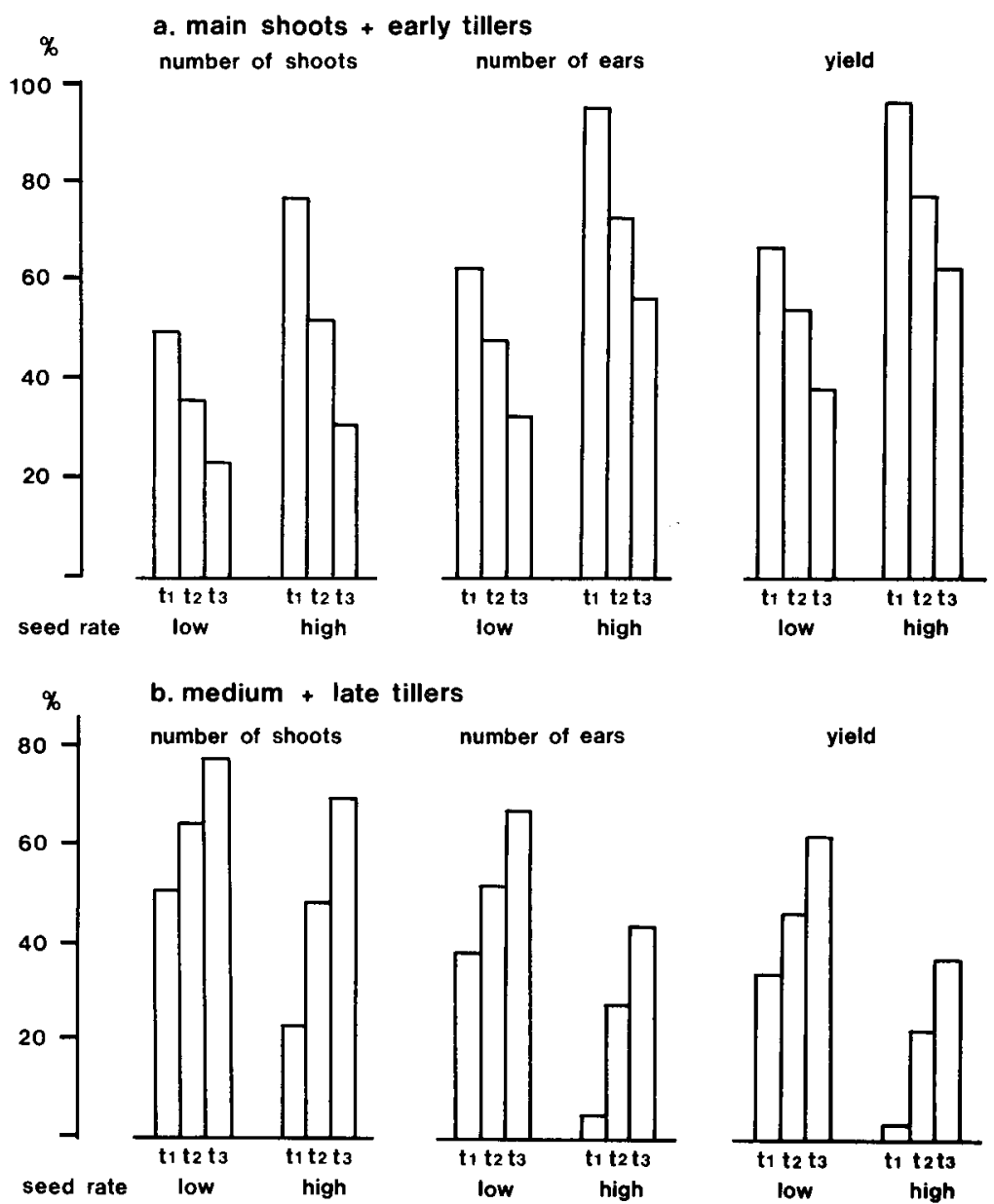

number of ears

yield

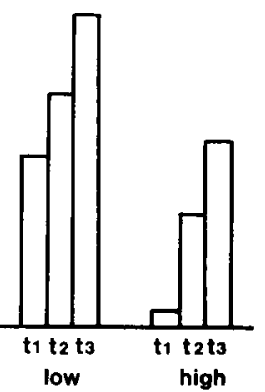

Fig. 1. Proportion of main shoots + early tillers (a) and medium + late tillers (b) in the number of shoots, the number of ears and the grain yield (relative notes).

On the other hand, the main shoots of the late-sown wheat were considerably less developed, and the inter-plant competition would have been smaller. In spring, abundant tillering occurred and at the end of April the greatest number of shoots was measured in the late-sown wheat crop.

In the early-sown wheat only a small part of the medium + late tillers was fertile. These tillers were located at the base of the plants, a position that is, for reasons of supply of light and minerals, unfavourable for further fertile development. In late-sown wheat, the growth conditions for medium + late tillers would have been better and this would have undoubtedly contributed to the increasing fertility of lateformed shoots with later sowing, as was found in the experiments. The fertility of medium + late tillers amounted to $42 \%, 57 \%$ and $59 \%$, respectively, at the low 
seed rate and to $9 \%, 25 \%$ and $35 \%$, respectively, at the high seed rate for the three sowing dates.

The influence of sowing date upon shoot development is even more marked in the distribution of ears, as can be seen in Fig. 1. Because of a higher fertility, main shoots and early tillers produced more ears than the medium + late tillers. Thus, the proportion of main shoots and early tillers was higher in the total number of ears than in the total number of shoots. Similar results were found by Krishnamurthy (1963) and Singh et al. (1972).

There were fewer ears of main shoots + early tillers in the later sowings; the reverse was true for the medium + late tillers. The proportion of medium + late tillers was smaller at the high seed rate, especially with early sowing.

The effect of sowing date and seed rate on the final number of ears was rather limited. The number of ears was only considerably increased by seed rate at the late sowing (Table $2 \mathrm{~b}$ ). At a low seed rate there were fewer ears in the late-sown wheat than in the earlier sowings. At a high seed rate more ears were produced than in the earlier sowings, resulting in a smaller yield reduction (Table 3 ).

\section{Number of grains}

With later sowing the number of grains per ear and the grain weight decreased (Table 5). Similar results were found by Beech \& Norman (1966), Kohn \& Storrier (1970) and Vez (1969), while Henriksen (1961) only established a decrease in the number of grains per ear. The number of grains per ear is controlled by the number of spikelets present and the number of grains per spikelet.

Initiation of spikelets in wheat is established in the very early stages of ear development. The rate of plant development during these stages depends upon growing conditions and strongly influences the number of spikelets. A slow development caused by short daylengths or low temperatures enhances the number of spikelets (Friend et al., 1963; Thorne et al., 1968). The retarded development of late wheat varieties in short days also results in increased spikelet production (Allison \& Daynard, 1976; Rawson, 1970).

The fertility of the initiated spikelets depends largely on growing conditions. With a higher light intensity more spikelets produce grains (Friend, 1965; Willey \& Holliday, 1971). Within each ear the numbers of florets and grains produced have been found to be closely connected with the rate of spikelet differentiation (Kirby, 1974). Also, differences in spikelet numbers between winter wheat and spring wheat can be associated with their rate of development (Pinthus, 1967). In perennial ryegrass similar ralationships between spikelet number and rate of development have been found (Kleinendorst \& ten Hove, 1957; Kleinendorst \& Sonneveld, 1965).

In our experiments clear differences in the rate of development existed between sowing dates and between tillers of various ages. Although not ascertained, the quick development of the late-sown crop and of the late-formed tillers would have limited spikelet inititation and differentiation, therefore resulting in fewer grains per ear (Table 5). Beech \& Norman (1966) found a decrease in spikelet number with later sowing, which coincided with a shortening of the related growth stages.

The rate of development can be considered as an important factor in explaining 
the differences in number of grains per ear between the sowing dates and between the tillers of different ages. So, the faster development of the late-sown wheat would have resulted in fewer grains per ear. The small number of grains in ears of lateformed tillers can be similarly explained. In main shoots and early tillers, the initiation and differentiation of spikelets would have been favoured by a rather slow development, and so more grains would have been produced. Similar effects of tiller age have been described by Krishnamurthy (1963).

The number of grains in ears grown from shoots of similar age, was not equal, but depended upon sowing date and seed rate (Table 5). With later sowing and a higher seed rate the number of grains per ear of these tillers decreased. Because spikelets were not counted and the age of the tillers was based on time of emergence and not on time of initiation, a definitive explanation cannot be given. However, it is likely that sowing date affects spikelet initiation, whereas seed rate affects the development of florets.

\section{Weight of grains}

The grain weight largely depends on growth conditions during the grain-filling period, and as such, annual fluctuations occur (Table 4). Grain weight and the length of the grain-filling period were closely related. In 1975 this period was long, but in 1976 it was very short because of drought and high temperatures. The grain weights were high in the early-sown wheat. With later sowing the grain weights decreased; this is undoubtedly connected with a shorter grain-filling period.

The effect of tiller age upon the grain weight can be similarly explained. The grain-filling period of main shoots is long and so the grain weights are high. With later-formed tillers this period is shorter and the grain weights are lower.

The effect of tiller age upon the grain weight was greatest at the first sowing date and decreased with later sowing. The position of the late and medium tillers was unfavourable in the vigorous crop of the first sowing date and so the growth of the grains in these tillers would have been restricted.

The influence of seed rate upon the grain weight was rather small (Table 3). Dense crops did not occur, so the growth of grains was similar in all treatments. Moreover, differences in number of ears between both seed rates were rather small.

\section{Conclusions}

Grain yield per ear depended upon tiller age (Table 5). Main shoots gave a high grain yield, because of a high number of grains and a high grain weight. Grain yields of the tillers were less, because there were fewer grains per ear and the grain weights were lower. This effect was greater the later the tillers were formed. These differences in grain yields of tillers varying in age, indicate that the composition of the crop can influence the final grain yield.

The early-sown wheat consisted largely of the high-yielding ears of main shoots and early tillers. In the late-sown crop a greater proportion of the ears came from medium and late tillers. The lower grain yield of these tillers predominantly contributed to the lower grain yield of the late-sown wheat. 
The seed rate influenced the number of ears per $\mathrm{m}^{2}$ (Table 2), the number of grains per ear (Table 5) and, to a lesser degree, the grain weights (Table 4). On the first two sowing dates, a higher seed rate had no influence on the grain yield, because the negative effect upon the number of grains per ear and the grain weight was compensated for by a greater number of ears per $\mathrm{m}^{2}$. At the late sowing date the high seed rate enhanced the number of ears so much that a higher grain yield was achieved. These results confirm practical advice to use higher seed rates with later sowing.

\section{Acknowledgment}

The authors are indebted to Ir J. H. J. Spiertz and Dr K. Dilz for their criticism and valuable comments and to Mrs. J. Boenisch Burrough for correcting the English text.

\section{References}

Allison, J. C. S. \& T. B. Daynard, 1976. Effect of photoperiod on development and number of spikelets of a temperate and some low-latitude wheats. Ann. appl. Biol. 83: 92-102.

Beech, D. F. \& M. J. T. Norman, 1966. The effect of time of planting on yield attributes of wheat varieties in the Ord River Valley. Aust. J. exp. Agric. Anim. Husb. 6: 183-192.

Dilz, K. \& J. H. Schepers, 1972. Stikstofbemesting van granen. Stikstof 6: 452-458.

Feekes, W., 1941. De tarwe en haar milieu. Verslag Technische Tarwecommissie, pp. 604-650.

Friend, D. J. C., 1965. Ear length and spikelet number of wheat grown at different temperatures and light intensities. Can. J. Bot. 43: 345-353.

Friend, D. J. C., J. E. Fisher \& V. A. Helson, 1963. The effect of light intensity and temperature on floral initiation and inflorescence development of Marquis wheat. Can. J. Bot. 41: $1663-1674$

Henriksen, Johs. Bak, 1961. Investigations on the sowing time of wheat. Acta Agric. scand. 11: 308-334.

Jonker, J. J., 1964. De stikstofbemesting van granen in de IJsselmeerpolders. Stikstof 4: 206-212.

Kirby, E. J. M., 1974. Ear development in spring wheat. J. agric. Sci., Camb. 82: 437-447.

Kleinendorst, A. \& H. J. ten Hove, 1957. Onderzoek aan het groeipunt bij enkele grassen. Jaarb. Inst. biol. scheik. Onderz. LandbGewassen: 39-49.

Kleinendorst, A. \& A. Sonneveld, 1965. Influence of the vernalization period and light intensity on shooting and composition of the inflorescence of perennial ryegrass (Lolium perenne $\mathbf{L}$.). Jaarb. Inst. biol. scheik. Onderz. LandbGewassen: 49-55.

Kohn, G. D. \& R. R. Storrier, 1970. Time of sowing and wheat production in southern New South Wales. Aust. J. exp. Agric. Anim. Husb. 10: 604-609.

Krishnamurthy, K., 1963. Studies in the physiology of yield of cereals. Ph. D. thesis, University of Reading.

Laloux, R., J. Poelaert \& A. Falisse, 1975. Stikstofbemesting bij graangewassen. Landbouwtijdschrift 5: 1155-1184.

Mundy, E. J. \& S. P. McClean, 1965. Winter wheat trials at Experimental Husbandry Farms and the Norfolk Agricultural Station. Expl Husb. 12: 146-163.

Pinthus, M. J., 1967. Evaluation of winter wheat as a source of high yield potential for the breeding of spring wheat. Euphytica 16: 231-251.

Rawson, H. M., 1970. Spikelet number, its control and relation to yield per ear in wheat. Aust. J. biol. Sci. 23: 1-15.

Ridder, J. K., 1976. Zaaizaadhoeveelheden en stikstofbemesting bij wintertarwe. Bedrijfsontwikkeling 7: 845-850. 
Singh, R. D., B. N. Chatterjee \& S. N. Sanyal, 1972. Tillering pattern in tall and dwarf wheat varieties under different levels of nitrogen and spacing. Indian J. agric. Sci. 42: 42-47.

Spiertz, J. H. J., 1973. Effects of successive applications of maneb and benomyl on growth and yield of five wheat varieties of different heights. Neth. J. agric. Sci. 21: 282-296.

Thorne, G. N., M. A. Ford \& D. J. Watson, 1968. Growth, development, and yield of spring wheat in artificial climates. Ann. Bot. 32: 425-446.

Vez, A., 1969. Influence de diverses mesures culturales sur les facteurs de productivité et le rendement de froment d'automne Probus. Rech. agron. Suisse 8: 175-184.

Vez, A., 1971. Influence de la période de semis sur le rendement du froment d'automne. Revue suisse Agric. 3: 87-92.

Willey, R. W. \& R. Holliday, 1971. Plant population, shading and thinning studies in wheat. J. agric. Sci., Camb. 77: 453-461. 